\title{
Groundless Threat of Infringement of Patent
}

\author{
Dharmapuri Selvakumar Madhumitha \\ Tamil Nadu National Law University, Tiruchirappalli, India \\ Email: madhumithads865@gmail.com
}

How to cite this paper: Madhumitha, D. S. (2019). Groundless Threat of Infringement of Patent. Beijing Law Review, 10, 480-486. https://doi.org/10.4236/blr.2019.103029

Received: January 28, 2019

Accepted: June 1, 2019

Published: June 4, 2019

Copyright $\odot 2019$ by author(s) and Scientific Research Publishing Inc. This work is licensed under the Creative Commons Attribution International License (CC BY 4.0).

http://creativecommons.org/licenses/by/4.0/

\begin{abstract}
Research, innovation and development are the main characteristics of developing nation. India is one of them and is the main hub of innovation, research and development in the field of growth of intellectual Property Law. There are rights which are guaranteed and a law to protect the intellectual rights of a person when infringed. However, there occur instances where there exists a groundless threat of infringement. It may come in form of a letter, a suit or a summon copy. Such groundless threats are discouraged by law since it brings shame and damage to the aggrieved. This paper focuses on the concept of groundless threat under Indian Law in comparison with the Patent Law around the World.
\end{abstract}

\section{Keywords}

Threat, Infringement, Groundless, Intellectual, Right

\section{Introduction}

Innovation should be encouraged, so that development is achieved. The encouragement can be through the way of reward (Chopra, 2018). IP rights are given and protected by law so that on any infringement to IP, IP Rights can be enforced. However, there are many instances where this protection has brought shame and misuse to others (Shrivastava, 2011). Groundless threat maybe one of the instances where without any grounds for filing of the infringement, any suit or threat of infringement is filed or issued just in order to threaten or bring shame, damage to the aggrieved. To prevent this, the provision is provided in Patent Act, 1970 under Sec. 106 to prevent and penalize the IP owners to file under false pretentions of infringement (Sukumar \& Malhotra, 2009).

\subsection{Research Objective}

- To study and understand the concept of Groundless threat in patent; 
- To analyse the Groundless threat in relation to the infringement of patent;

- To study about the exception of groundless threat and infringement of patent.

The hypothesis will be studied, analysed and concluded based on the provisions for Groundless threat of patent infringement in statute: The Patent Act, 1970, Judicial Precedents and by comparison with other legislations such as UK, New Zealand and China.

\subsection{Research Question}

1) Whether there can be groundless threat of patent?

a) Whether such Groundless threat can lead to infringement of patent?

2) Whether there is exception where Groundless threat cannot amount to infringement of patent?

\subsection{Research Methodology}

This article would be a doctrinal based research. There are various methodologies used in this article, including Content Analysis Method with secondary data collection from books and articles. The methodology that is being adopted in the said project is purely doctrinal in nature. The research is completely relying on primary resources, such as statutes and also secondary resources such as notices, commentaries and various books of eminent authors have been referred and cited. The said research paper also has a high reliance on the study articles and other works of eminent universities/colleges and also websites have also been referred which can be viewed in the Bibliography.

\section{Threat and Groundless Threat}

Threat is to be determined from the perspective of the ordinary prudent man, how that communication would have been received by him. The threat becomes groundless when there is no basis of giving a threat to any person in case of infringement (Deepak, 2009). It can be either in writing or verbally produced comments or in newspaper advertisements or any form of communication which has no base of threat. Number of times communication is made, a single latter may constitute a groundless threat of infringement when viewed on whole and interpretation of a common prudent man. Example, when the Ip right is in itself is invalid or when there is no basis of infringement, a threat is made, such a threat would deem to be groundless (Indian Vakil, 2015). Infringement proceedings cost heavy than that of normal litigation suit, as it would look into the merits to grant temporary injunction. It leads to the loss of reputation and the business of a person. No person should unnecessarily go through this proceeding or the groundless threat.

LG Electronics India Pvt Ltd., v. Bharat Bholigal Patel \& ors, where the Delhi High Court held "if any proprietor or the right holder issues a notice to the custom officials and the custom officials act upon the same by restricting the imports of consignments of any party without the determination (Prima Facie or 
otherwise) of the factum of infringement of patent by the appropriate designated authority, then such notice by the right holder to the customs and the actions thereof by the customs either in the form of notice to that party or otherwise calling upon the party to explain its stand are all unnecessary illegal threats to that party" (George, 2014).

The case observes and decides on groundless threat of infringement that if any notice given by the proprietor or the right holder to the Custom officials, and it is not proved in prima facie of the notice that there is explicit infringement of patent, then any act done in pursuance of the notice either by the right holder or the custom officials calling upon the person to prove his innocence will be regarded as groundless threat of infringement.

Law provides protection to such victims of groundless threat under the IP Law. Example: Sec. 106 of Patent Act, 1970, Sec. 60 of Copyright Act, 1957, Sec. 142 of Trademarks Act, 1999.

\section{Relief of Groundless Threat}

Sec. 106 grants protection against the groundless threat mechanism used by few persons to gain advantage in the market or reduce the competition ${ }^{1}$. It grants relief to persons victimized of groundless threats, such aggrieved persons may bring the action of suit in the Court for seeking the Remedy against the use of groundless threat. The threats may be issued through circulars or advertisement or verbal or in writing to the person communicating the infringement of patent, there is also notification to the existence of the patent provided by the patent holder which does not contribute to the factor of groundless threat but mere communication of the information of the patent being in existence (Berurar, 2017).

The aggrieved or the victim of the groundless threat may bring the action in form of the suit in the Court of law against the acts of the plaintiff being unjustifiable and in continuance. The Court on hearing the petition made by the Plaintiff on the groundless threat may issue the following ${ }^{2}$ :

1) A declaration in the judgement of the court on the petition by the plaintiff that the threats are groundless and unjustifiable to be faced by the aggrieved.

2) An interim or permanent injunction to be issued in case of the baseless threat continuance to the aggrieved.

3) Any damages in case of loss suffered or reputation being damaged by such groundless threats can be claimed in the Court of Law to be reimbursed.

However, there is heavy burden on the aggrieved in order to prove that the threat of patent infringement is groundless and unjustifiable and that the patent of the communicator is invalid. In case the plaintiff fails, the BOP shifts to the

${ }^{1}$ Refer to Sec.106 for the provision on groundless threat of patent in Indian law, The Patents Act,1970, http://ipindia.nic.in/writereaddata/Portal/ev/sections/ps106.html, Last Accessed: $30^{\text {th }}$ Oct, 2018, also refer to Bajaj Auto Ltd Bombay Pune Road v. TVS Motor Company Ltd., 2009 (12) SC 103. See also, Hyderabad Chemical supplies Limited v. United Phosphorus Limited and anr, 2006(6) ALT515.

${ }^{2}$ Refer for detailed analysis to Royal Baking Powder co v. Wright, Crossley \& Co, [1901] 18 RPC 95 at 99 . 
defendant that there has been actual infringement of the right of defendant and either ask for an injunction or claim for the damages caused if any under the Provisions of Patent Act, 1970 (Joshi \& Das, 2014). But if the defendant fails to establish the existence of patent, him being the patent holder then such failure will lead to claim of remedy for threat by the plaintiff.

For the act of infringement to unfold every step, every essential element present in the patent object of the patent holder must be present in the registered article if not the action will eventually fail to succeed ${ }^{3}$.

\section{Case Laws}

\section{LG Electronics India Pvt Ltd., v. Bharat Bhogilal Patel \& Ors ${ }^{4}$}

The petitioner filed a petition in the Delhi High Court claiming that the Customs office, who is a defendant number two without approaching the Court is interdicting the imported goods of the plaintiff thereby amounting to the act of groundless threat. The patent of Bharat Bhogilal Patel "Process of Manufacturing engraved design Articles on metals or non metals". The plaintiff received a show cause notice by the defendant taking the offence of attacking the novelty and inventive step of the patent. Petitioner filed before the IPAB challenging the impugned patent the interdicting of the imported goods happened in continuance by the customs despite the fact that the case was pending, eventually the case came before the Court.

\section{Decision:}

The Court ordered an interim order, an injunction in favor of the plaintiff against the customs office. When there is no prima facie infringement of patent right in intellectual property, any action taken or notice rendered to make a stand of his innocence would be amounting to a groundless threat of infringement.

\section{Bata India Limited v. Vitaflex Mauch $G m b H^{5}$}

There was notice received by the Bata from Vitaflex:

The defendant was a distributor of the marketed shoes under the brand "by doc Mauch" or "Nach Dr. Mauch. The shoe was designed on the basis of five-point pressure and the trademark for it was still pending. The patent application is also pending for the vitaflex. The only difference which could be brought to notice was the pressure point, Bata had six pressure point configuration while Vitaflex had five. The notice was issued by Vitaflex that there was infringement of Vitaflex's trademark rights and that of patent.

This is a case of groundless threats by the defendants against the plaintiffs, the plaintiff brought forth to the notice of the Delhi High Court that the threat was unjustified and no IP rights of the defendant was violated by the plaintiff. There ${ }^{3}$ Infra Note. 14

${ }^{4}$ For further details refer to, LG Electronics India Pvt Ltd v. Bharat Bhogilal Patel \& Ors, 2012 (51) PTC 513 (Del.)

${ }^{5}$ As decided in Bata India Limited v. Vitaflex Mauch Gmbh, IA NO. 9594 OF 2007 IN CS(OS) NO. 1112 OF 2006. Decided on 13 February 2008. 
was further more claim of damages for the groundless threats by the defendants.

The contention brought by BATA was that the patent filed by Vitaflex is still pending and is not yet registered to be violated. The second contention was that PCT application only claims novelty in the thickness and material of the insole whereas number of pressure points, there is no protection. The point in question was whether bata is eligible for claims of damages and injunction (Verma, 2017).

\section{Decision}

Unless the Defendant had a registered IP protection for the claimed patent, the act of the defendant to the plaintiff will amount to the groundless threat and violation of the provision under Patent Act, 1970 Sec. 106. since the Defendant didn't establish valid pressure point patent, the plaintiff can claim damages. While relying on further provisions such as Sec. 48, Sec. 52(3) and Sec. 70 of the Patents Act, 1970 said that for an infringement to occur there needs to be granted patent to the person who has issued the threat. Therefore, holding the threats to be unjustifiable, groundless, the court passed a relief from issuing groundless threat to the plaintiff.

\section{Comparison with Other Countries}

Deterring infringers is the reason why Groundless threats are tools which are used by the patent holders. It can potentially lead to deterring the competitors and come to a settlement in case of a company.

\subsection{New Zealand}

New Zealand as well as England provide for unjustified threats and groundless infringement. In New Zealand, the IP Rights in issue is the determining factor in unjustified threats and proceedings. This turns unfavourable as there can be more than one IP rights for one person in more than one territory (Gray et al., 2017). There is no separate Act as that of UK for Unjustified threats, like in India, New Zealand to protect the interest and rights of the Intellectual property right owner, has a provision in its New Zealand Patent's Act, 2013 under Sec. 74, however there exist no specific remedy but the defendants can under Sec. 147 do a counter claim to revoke the patent and can also apply for non-infringement declaration to the court under Sec. 159 of Patent Act, 2013. ${ }^{6}$

\subsection{Intellectual Property (Unjustified Threats) Act 2017, United Kingdom}

This is a separate Act which provides remedies and protection for the IP holders and Aggrieved parties (Horton, 2017). Highlights are as follows:

- "Person aggrieved" is the criteria for seeking remedies for unjustified threat of infringement proceedings. Persons other than parties to whom the threat

${ }^{6}$ For further details, Sec.147 and Sec.159, New Zealand Patent Act, 2013. 
is made can also claim for the relief. ${ }^{7}$

- The test for determining the factor for determination of the groundless threat is that, the threat should be viewed from point of view of a prudent reasonable man. ${ }^{8}$

- "Permitted Communications" are given to the IP holders, who can make communications through a notice about their rights and the patent or any IP they hold in their name without actually issuing a threat or creating a liability upon them ${ }^{9}$.

- Professional advisers of the parties are exempt ${ }^{10}$.

\subsection{IP Threat in China}

The patent owner should fulfil all his dutiful prudential obligations and be careful while issuing a notice of threat otherwise it will end up being a commercial slander. The court has decided in the case of Shuanghuan v. Honda, Requirements for issuing warning letters: it should have a legitimate purpose ${ }^{11}$. Valid Patent should be already existing for the person to be claiming infringement of IP, Detailed Content. ${ }^{12}$

\section{Conclusion}

Threats in IPR can be very demeaning to a lot of innovators and inventors as they hope to develop and research more on the field of expertise. It is important to know the rights in rem which the party holds when there is abuse of their intellectual property. This study brings the awareness to the parties as to what are the remedies available to the aggrieved in a groundless threat of infringement and how they can be protected against such abuse. Such unjustifiable threats should not hinder the research and development of a person but should be a step forward to innovation, as the law is there to protect their legitimate right and provide for safe and secure environment for development.

Indian Patent Law provides for protection to the aggrieved and protection against infringement to the patent holder. Groundless unjustifiable threats hinder the process of research and development and bring to the inventors and innovators a shame and loss to the reputation, which will in turn affect the company. It is best to follow the UK principles which have a separate legislation to govern the threats which are groundless in every aspect of IP, thereby giving more space for the innovators to improve upon and contribute to the society. The persons who can claim along with improvements in the test of groundless threat have also improved in the UK legislation of Intellectual Property (Unjustified Threats) Act, 2017.

\footnotetext{
${ }^{7}$ For better understanding refer to, Sec. 70(2), Patents act, 1977.

${ }^{8}$ Refer to Sec. 70(1), Patents Act 1977.

${ }^{9}$ For detailed analysis refer to Sec.70B(2), Patents Act 1977, see also, Sec. 70A(5), Patents Act 1977.

${ }^{10}$ For fine analysis refer to Sec. 70D(3), Patents Act 1977.

${ }^{11}$ Refer to Article 11, PRC Anti-Unfair Competition Law, 2017.

${ }^{12}$ As decided in Shuanghuan v Honda, 2008 SCC 39 see also, Shenzhen Libang Precision Instrument co Ltd v Shenzen Mairui Biological Medical Electronic Co, Law china, 2016.
} 
The Article could be better focused and improved as per the comparison of other countries in protection of the aggrieved in groundless threat of patent to the Indian Patent Act, 1977 and also focused on more Judicial precedents to have a better understanding as to the position of the aggrieved and the analysis of remedy available for protection against the society.

\section{Conflict of Interest}

The author declares no conflicts of interest regarding the publication of this paper.

\section{References}

Berurar, R., \& Sinha, J. (2017). India: Protection against Groundless Threats under Indian IP Laws.

http://www.inhousecommunity.com/article/india-protection-groundless-threats-india n-ip-laws/

Chopra, D. S. (2018). A Book on Indian Patenting System and Patent Agent Examination. https://books.google.co.in/books?id=3dFqDwAAQBAJ\&pg=PT511\&lpg=PT511\&dq=S ec. $106+$ Patent + Act $+1970 \&$ source $=$ bl\&ots $=q$ fuCPKZzMy\&sig $=$ NackFBg8gShLd7Z2eQ czvIq97EM\&hl=en\&sa=X\&ved=2ahUKEwi09Z_0r6zeAhWTUn0KHflNBeg4HhDoAT AGegQIARAB\#v=onepage\&q=Sec.106\%20Patent\%20Act\%201970\&f=false

Deepak, J. S. (2009). De-Coding Indian Intellectual Property Law. https://spicyip.com/2009/12/ss105-and-106-of-patents-act_21.html

George, M. P. (2014). Spicy IP, Guest Post: Groundless Threat of Infringement Proceedings - A Comparison Spanning a Few India IP Legislations.

https://spicyip.com/2014/09/guest-post-groundless-threat-of-infringement-proceeding s-a-comparison-spanning-a-few-india-ip-legislations.html

Gray, E., Watts, R., \& Grierson, S. (2017). Putting Your Money Where Your Mouth Is. https://www.simpsongrierson.com/articles/2017/putting-your-money-where-your-mo uth-is

Horton, A. (2017). Intellectual Property (Unjustified Threats) Act, 2017. https://www.twobirds.com/en/news/articles/2017/uk/it-and-ip-law-bytes-june-2017/int ellectual-property-unjustified-threats-act-2017

Indian Vakil (2015). Patent Infringement in India. https://jashvaidya.wordpress.com/2015/11/26/patent-infringement-in-india/\#_ftn1

Joshi, A., \& Das, P. (2014). Groundless Threat of Patent Infringement. http://www.mondaq.com/india/x/628598/Patent/GROUNDLESS+THREAT+OF+PAT ENT+INFRINGEMENT

Shrivastava, R. (2011). Infringement of Patent-Part II. http://www.mightylaws.in/760/patent-infringement-part-ii

Sukumar, S., \& Malhotra, T. (2009). India: Review of Indian Patent Law in 2008. http://www.mondaq.com/india/x/80832/Patent/Review+Of+Indian+Patent+Law+In+2 $\underline{008}$

Verma, A. (2017). Groundless Infringement Threats. https://www.lakshmisri.com/News-and-Publications/Publications/Articles/IPR/ground less-infringement-threats 